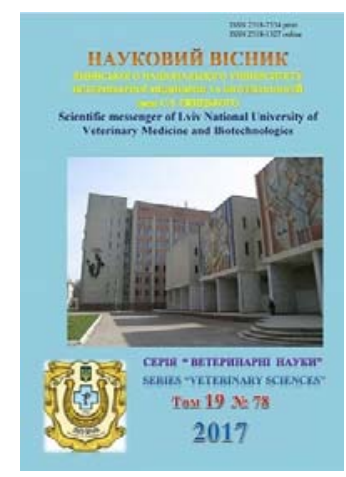

Науковий вісник Львівського національного університету ветеринарної медицини та біотехнологій імені С.З. Гжицького

Scientific Messenger of Lviv National University of Veterinary Medicine and Biotechnologies

doi:10.15421/nvlvet7824

ISSN 2518-7554 print

ISSN 2518-1327 online

$\underline{\text { http://nvlvet.com.ua/ }}$

УДК 619:576.895.1:636.2

\title{
Порівняльна оцінка препаратів фенбендазолу за інвазії курей-несучок нематодами Heterakis gallinarum
}

\author{
М.М. Данко, О.Л. Тішин, Р.В. Хом'як, Ж.М. Періг \\ parasitol@ukr.net
}

Державний науково-дослідний контрольний інститут ветеринарних препаратів та кормових добавок вул. Донецькка, 11, м. Львів, 79019, Україна

\begin{abstract}
У статті наведено дані щодо ефективності двох вітчизняних препаратів для перорального застосування на основі фенбендазолу: «Феборал» (у формі розчину) та «Бровадазол 20\%» (референс препарату у формі пороику). 3 иією метою були проведені дослідження на курях-несучках 420-добового віку, яких обстежили копроскопічно методом флотачії з метою виявлення кишкових інвазій. терапевтичну ефективність препаратів визначали за даними копроскопічних обстежень, які проводили із застосуванням модифікованого кількісного методу Мак-Мастера. Дослідження ефективності препаратів «Феборал» та «Бровадазол 20\%» виконано в умовах віварію Державного науково-дослідного контрольного інституту ветеринарних препаратів та кормових добавок.

Упродовж експерименту птахам дослідних груп застосовували препарати на основі фенбендазолу: курям першої дослідної групи препарат «Феборал» випоювали з водою (1,0 мл препарату на 10 кг м. т., двічі впродовж двох діб), другої - препарат «Бровадазол 20\%» задавали з кормом (0,5 г препарату на 10 кг м. m. впродовж n'яти діб). Птахам контрольної групи випоювали воду та згодовували корм без вмісту препаратів.

За результатами досліджень у курей-несучок встановлено інвазію збудником Heterakis galinaruт. Середній показник інтенсивності інвазї курей-несучок нематодами до обробки препаратами складав 176 яєць у 1 г посліду. У курей пермої та другої дослідних груп середня інтенсивність інвазї гельмінтами на сьому добу експерименту складала 84,5 яєиь у 1 г посліду, тимчасом як показник інтенсивності інвазії курей контрольної групи становив 211 яєиь у 1 г посліду. На чотирнадияту добу експерименту виділення яєць збудника у курей обох дослідних груп не встановлено, тимчасом як у курей контрольноі групи інтенсивність інвазії становила 238 яєць гетеракісів у 1 г посліду.

Отже, екстенсефективність препарату «Феборал» та референс препарату «Бровадазол 20\%» за гетеракозу курей становила $100 \%$.

Ключові слова: кури, гельмінтози, нематодози, інтенсивність інвазї̈, гетеракоз, дегельмінтизація, фенбендазол, ексиенсефективність, Феборал, Бровадазол 20\%.
\end{abstract}

\section{Сравнительная оценка препаратов фенбендазола при инвазии кур-несушек нематодами Heterakis gallinarum}

\author{
Н.Н. Данко, А.Л. Тишин, Р.В. Хомяк, Ж.Н. Периг \\ parasitol@ukr.net
}

Государственный научно-исследовательский контрольный институт ветеринарных препаратов и кормовых добавок, ул. Донеикая, 11, г. Львов, 79019, Украина

В статье приведены данные по эффективности двух отечественных препаратов для перорального применения на основе фенбендазола: «Феборал» (в форме раствора) и «Бровадазол 20\%» (референс препарат в форме порошка). $C$ этой целью были проведены исследования на курах-несушках 420-суточного возраста, которых обследовали копроскопически методом флотации с иелью выявления кишечных инвазий. Терапевтическую эффективность препаратов определяли по

\section{Citation:}

Danko, M.M., Tishyn, O.L., Khomiak, R.V., Perih, Zh.M. (2017). Comparative evaluation of fenbendazole drugs against nematode invasion by Heterakis gallinarum. Scientific Messenger LNUVMB, 19(78), 118-120. 
данным копроскопических исследований, которые проводили с применением модифицированного количественного метода Мак-Мастера. Исследование эффективности препаратов «Феборал» и «Бровадазол 20\%» выполнены в условиях вивария Государственного научно-исследовательского контрольного института ветеринарных препаратов и кормовых добавок.

В течение эксперимента птицам опытных групп задавали препараты на основе фенбендазола: курам первой опытной группь препарат «Феборал» выпаивали с водой (1,0 мл на 10 кг м. т., дважды в течение двух суток), второй - препарат «Бровадазол 20\%» задавали с кормом (0,5 г препарата на 10 кг м. т., в течение пяти суток). Птицам контрольной группьл випаивали воду и скармливали корм без содержания препаратов.

По результатам исследований у кур-несушек установлено инвазию возбудителем Hеterakis galinarum. Cредний показатель интенсивности инвазии кур-несучек нематодами перед применением препаратов составлял 176 яии в 1 г помета. У кур первой и второй опьттых групп средняя интенсивность инвазии гельминтами на седьмые сутки эксперимента составляла 84,5 яиц в 1 г помета, тогда как показатель интенсивности инвазии кур контрольной группь составил 211 яиц в 1 г помета. На четырнадцатые сутки эксперимента выделение яиц возбудителя у кур обоих опытных групп не отмечали, в то время как у кур контрольной группы интенсивность инвазии составила 238 яиц гетеракисов в 1 г помета.

Таким образом, экстенсэффективность препарата «Феборал» и референс препарата «Бровадазол 20\%» при гетеракозе кур составила $100 \%$.

Ключевые слова: куры, гельминтозы, нематодозы, интенсивность инвазии, гетеракоз, дегельминтизация, фенбендазол, экстенсэффективность, Феборал, Бровадазол 20\%.

\title{
Comparative evaluation of fenbendazole drugs against nematode invasion by Heterakis gallinarum
}

\author{
M.M. Danko, O.L. Tishyn, R.V. Khomiak, Zh.M. Perih \\ parasitol@ukr.net

\begin{abstract}
State Scientific-Research Control Institute of Veterinary Medicinal Products and Feed Additives, Donetska Str., 11, Lviv, 79019, Ukraine
\end{abstract}

The article presents data on the effectiveness of two fenbendazole-based drugs for oral application: «Feboral» (in the form of a solution) and "Brovadazol 20\%» (the reference drug in the form of powder). For this purpose, 420-day-old chickens were examined by a flotation coproscopic method in order to detect intestinal invasions. The therapeutic efficacy of the drugs was determined according to the data of the coproscopic examinations carried out using the modified quantitative McMaster counting method. The study of the efficacy of "Febboral» and «Brovadazol 20\%» preparations was performed under the conditions of vivarium of the State scientific-research control institute of veterinary medicinal products and feed additives.

During the experiment birds of experimental groups used preparations on the basis of fenbendazole: hens of the first experimental group, the drug «Feboral» was poured out with water $(1.0 \mathrm{ml}$ of the preparation for $10 \mathrm{~kg}$ of $\mathrm{b}$. w., twice for two days), the second - the drug «Brovadazol 20\%» they were given with food (0.5 g of the preparation at $10 \mathrm{~kg} \mathrm{~b}$. w., for five days). Birds in the control group were given water and food without the contents of drugs.

According to the results of research in hens were found invasion by Heterakis galinarum. The average rate of invasion of hens by nematodes during treatment with drugs was 176 eggs per $1 \mathrm{~g}$ of litter. In the hens of the first and second experimental groups, the average intensity of the helminth infestation on the seventh day of the experiment was 84.5 eggs per $1 \mathrm{~g}$ of litter, while the intensity of the infection of the control group was 211 eggs per $1 \mathrm{~g}$ of litter. On the fourteenth day of the experiment, the excretion of eggs from the pathogen in the hens of both experimental groups was not noted, while in the hens of the control group, the intensity of the invasion amounted to 238 eggs heterakis in 1 gram of litter.

Consequently, the extenseffectivity of the drug «Febboral» and the reference drug «Brovadazol 20\%» for heterakoses of chickens was $100 \%$.

Key words: chickens, helminthiasis, nematodosis, intensity of invasion, heterakosis, dehelminthisation, fenbendazole, extenseffectivity, Feboral, Brovadasol $20 \%$.

\section{Вступ}

Паразитарні захворювання, зокрема нематодози, є значною проблемою птахівницва, яка особливо актуальна за безкліткового утримання свійських птахів. Значна роль належить збудникам роду Heterakis, що спричиняють захворювання свійських птахів, які супроводжуються, головним чином, ураженням травного каналу, появою діареї з домішками крові, дегідратації, анорексії, виснаженням. Дана інвазія рідко спричиняє загибель птахів, проте завдає значних економічних втрат птахогосподарствам яєчного, м'ясояєчного та м'ясного напрямку, які проявляються насамперед у відставанні в рості молодняку, зниженні яйценосності дорослих птахів та погіршенні якості готової продукції (Tiersch et al., 2013).
3 лікувально-профілактичною метою за нематодозів свійської птиці у ветеринарній медицині застосовують переважно препарати альбендазолу, левамізолу (Tucker et al., 2017), мебендазолу та фенбендазолу (Tomza-Marciniak et al., 2014).

Метою роботи було вивчення ефективності препарату «Феборал» у формі розчину за спонтанної інвазії курей збудником гетеракозу порівняно 3 препаратом «Бровадазол 20\%».

Фенбендазол (5 (фенілтіо)-2-бензимідазол карбамінова кислота метиловий ефір) антигельмінтна речовина широкого спектру дії, яка виявляє високу ефективність стосовно до незрілих та дорослих форм збудників нематодозів. Механізм дії фенбендазолу полягає у гальмуванні полімеризації білків $\beta$-тубулінів в мікротубуліни, знижує активність 
енергетичних процесів (АТФ та синтезу глюкози), що спричиняє параліч м'язів та призводить до загибелі паразита (Lekdumrongsak et al., 2014).

\section{Матеріал і методи досліджень}

Дослідження з ефективності препарату «Феборал» за гетеракозу курей виконували в лабораторії контролю протипаразитарних препаратів та дезінфікуючих засобів ДНДКІ ветеринарних препаратів та кормових добавок в умовах віварію. Дослідження були проведені на курях-несучках 420-добового віку. До постановки експерименту всі кури були обстежені копроскопічно флотаційним методом 3 метою виявлення кишкових інвазій. Для кожної серії дослідів відбирали відповідну кількість курей, спонтанно інвазованих нематодами Heterakis gallinarum, з яких було сформовано, відповідно до загальних правил за принципом аналогів, дві дослідні та одну контрольну групу. Впродовж усього експерименту птахам дослідних груп задавали препарати на основі фенбендазолу: курям першої дослідної групи випоювали 3 водою

препарат «Феборал» (1,0 мл препарату на 10 кг м. т. двічі впродовж двох діб), другої - задавали з кормом препарат «Бровадазол 20\%» (0,5 г препарату на 10 кг м. т. впродовж п'яти діб). Залежно від лікарської форми препарати вносили у воду або корм, ретельно перемішували та задавали відповідно до добової потреби курей. Птахам контрольної групи випоювали воду та згодовували корм без препаратів.

Терапевтичну ефективність препаратів визначали за даними копроскопічних обстежень, які проводили iз застосуванням модифікованого кількісного методу Мак-Мастера (Taylor et al., 2010).

Ідентифікацію нематод проводили за визначником. Біометрію яєць проводили за допомогою мікроскопа, за збільшення $\times 100$.

\section{Результати та їх обговорення}

За результатами досліджень 3 вивчення ефективності препарату «Феборал» за нематодозів свійської птиці встановлено інвазію збудником Heterakis galinarum (табл. 1).

Таблиия 1

Динаміка інвазованості курей-несучок збудником гетеракозу до та після застосування препаратів «Феборал», «Бровадазол $20 \%$ \%, $(\mathbf{n}=\mathbf{1 0})$

\begin{tabular}{|c|c|c|c|}
\hline \multirow{3}{*}{ Групи курчат } & \multicolumn{3}{|c|}{$\begin{array}{c}\text { Інтенсивність інвазії гетеракісами до } \\
\text { та після застосування препаратів }\end{array}$} \\
\hline & \multirow{2}{*}{ до застосування } & \multicolumn{2}{|c|}{ доби експерименту } \\
\hline & & 7 & 14 \\
\hline Дослідна 1 «Феборал» & $177 \pm 5,17$ & $84 \pm 3,71$ & 0 \\
\hline Дослідна 2 «Бровадазол 20\%» & $175 \pm 5,63$ & $85 \pm 3,41$ & 0 \\
\hline Контрольна & $176 \pm 4,99$ & $211 \pm 4,58$ & $238 \pm 3,89$ \\
\hline
\end{tabular}

Середній показник інвазованості курей-несучок збудником гетеракозу до обробки препаратами складав 176 яєць у 1 г посліду (ЯГП).

У курей першої та другої дослідних груп середня інтенсивність інвазії (II) гетеракісами на сьому добу експерименту становила 84,5 ЯГП, тимчасом як показник II нематодами курей контрольної групи складав 211 ЯГП.

На чотирнадцяту добу експерименту виділення яєць збудника гетеракозу в посліді курей обох дослідних груп не встановлено, тимчасом як у необроблених курей II гетеракісами становила 238 ЯГП.

Отже, екстенсефективність препарату «Феборал» та «Бровадазол 20\%» за гетеракозу становила $100 \%$.

\section{Висновки}

За результатами проведених досліджень встановлено 100\% екстенсефективність антгельмінтних препаратів на основі фенбендазолу «Феборал» та «Бровадазол 20\%» за гетеракозу курей. Тотальна елімінація нематод Heterakis galinarum 3 травного каналу курей обох дослідних груп завершилась до чотирнадцятої доби після застосування препаратів.

Перспективи подальших досліджень. Планується проведення вивчення ефективності різних форм пре- паратів на основі фенбендазолу за нематодозів водоплавних птахів.

\section{Бібліографічні посилання}

Tiersch, A., Das, G., von Samson-Himmelstjerna, G., Gauly, M. (2013). Artificial infection of chickens with Capillaria obsignata eggs embryonated in different media. Vet. Par., 1-7.

Tucker, C.A., Yazwinski, T.A., Reynolds, L. (2017). Determination of the Anthelmintic Efficacy of Albendazole in the Treatment of Chickens Naturally Infected with Gastrointestinal Helminths. Poult. Sci. Ass. Inc., 392-396.

Tomza-Marciniak, A., Pilarczyk, B., Tobiańska, B., Tarasewicz, N. (2014). Gastrointestinal parasites of free-range chickens. Ann. Parasitol. 60(4), 305-308.

Lekdumrongsak, T., Tiawsirisup, S., Banlunara, W. (2014). Efficacy of Fenbendazole against Ascaridia Spp. in Large Macaws. Thai. J. Vet. Med. 44(20), 231-235.

Taylor, M.A., Coop, R.L., Wall, R.L. (2010). Veterinary Parasitology. Blackwell Pub., 1006.

Received 18.09.2017 Received in revised form 9.10.2017 Accepted 13.10.2017 